\title{
Relational leadership and the missional church
}

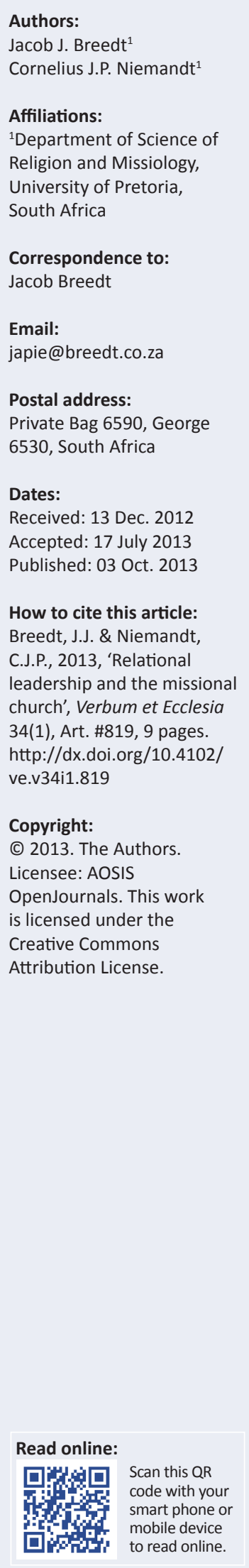

The global realities regarding cultural shifts and the transition between traditional, modern and postmodern world perspectives have particular implications for leadership in general. In several institutions, including those in commercial, educational, medical and religious circles, leaders face the challenges of constant change in lifestyle, relational intelligence and responsibility. The combined impact of these changes in thought and culture, information technology, globalisation and racial, ethnic and religious pluralism has displaced the historic role the church has traditionally played. In this article it was argued that the church would have to take a hard look at relationships, in order to be the successful missional church which was demonstrated by Jesus Christ. The church needs to change, evolve and advance in relational intelligence and leadership - and leaders should set the pace. This implies that a paradigm shift is necessary; it is believed that this can be achieved through the proposed relational leadership style, as clearly demonstrated in the Trinitarian discussion. The Trinity, especially a relational Trinity, revealed the core understanding of missional ecclesiology and leadership and showed that as a result of the total 'oneness' of God, there is no hierarchical order in the Godhead and as such the church should function and operate with the Trinity as its model and example.

\section{Introduction}

Living in an age where people value honesty and truthfulness, openness, integrity and relationships above titles and authority, leaders cannot lead from their leadership positions unless they are in a good relationship with the people around them. Spirituality that does not make a difference in the lives of people is rapidly losing favour. Christians are tired of religious programmes, performances or 'religious games' (Barna 2005:13) and want to be part of a church which is led by the Holy Spirit, progressing towards feeding the hungry, healing the sick, and giving hope and purpose to the lives of those in need. Christ's followers want to be part of a church that is an active change agent in the world. Christians with this passion face huge challenges and these will not be resolved unless the church involves itself in the world around it.

South Africa is experiencing a time of distorted relationships and 'divide and rule' (Limb 2008:loc 606) leadership hierarchies. In his statement in the Rivonia trial in the Pretoria supreme court, Nelson Mandela declared that 'unless responsible leadership was given to canalise and control the feelings of our people, there would be outbreaks of terrorism which would produce an intensity of bitterness and hostility' (Mandela 2011:loc 97-98). After all these years, South Africa still needs relational leadership bridges to be built across racial and cultural divides.

God is a missional God. The self-diffusive, gathering, and sending nature of God means that missionality starts with a relationship, a going beyond oneself, being in relation and calling others to relation (Bevans \& Schroeder 2011:10). 'God is love' (1 Jn 4:8) ${ }^{1}$ is the core and essence of God. It is because of this $\alpha \gamma \alpha \dot{x} \eta$ [love] that is shared within the Trinity and with his creation that God sent his Son as redeemer to a lost world to restore the broken relationship between the world and him.

God's relationship with the world belongs to his eternal being (Flett 2010:34) and that relationship constantly finds its expression through the work of the Holy Spirit, encouraging, helping, leading, supporting and teaching his church. This article on leadership in the church is embedded in an understanding of the church and what the church is. The church is, like the Christian faith itself, a Trinitarian experience of God (Moltmann 2010:26). Christian community should therefore be a relational and missional community, or it cannot be seen as a community that lives in fellowship with the Triune God.

The church does what it is and then organises what it does. Leadership is an organisational challenge, and the nature of the church determines the nature of appropriate leadership. Urgent

1.All Bible scriptures are quoted from the New International Version. Zondervan Publishing House. Grand Rapids. 
and increasingly peremptory demands are being made on the church to rethink leadership.

\section{Triune God: Relational and missional}

Writing about God is and will always be a very humbling experience for any writer. Nobody will ever be able to define, fully understand or analyse God and therefore must rely heavily on a personal understanding of God's self-revelation. The community of the Father, Son and Holy Spirit becomes the prototype of the human community. Grenz (2004) states:

In fact, the assumption that the most promising beginning point for a viable Trinitarian theology lies in the constellation of relationships amongst the three Trinitarian persons that has become so widely accepted that it attained a kind of quasiorthodox status. (p. 117)

The understanding is therefore that 'persons' is used within a human frame of reference, trying to describe an indefinable God. It is not trite to say that the triune God stands at the very beginning and end of Christian life and faith: "The nature of God's being, not just God's commands, is integral to the character of Christian beginnings and ends' (Volf \& Welker 2006:3).

Missionality is fuelled by nurturing relationships, lovedriven by the Holy Spirit from the heart of God. God loved the world enough to send his Son on a mission to build a redemptive relationship with his creation (Cole 2005:loc 1496-1498). Mission cannot be successful without building relationships with those who are not living in relation with Christ or are even opposing belief in Christ. The model of a true and perfect relationship lies within the Trinity and the Godhead, modelling and illustrating mission through the life of the Trinity (Balia \& Kim 2010:20). The main thrust of this article is that a theory of relational missionality, built on the life of the church in Trinitarian community and relationality, will assist the church in its missional task. This is possible when church leadership is understood in terms of the missio $D e i$, and functions as an agent of 'God's redemptive initiative' in the world as he acts with love through the church (Tennent 2010:1oc 701).

God himself rolled out an emancipating act through Jesus Christ and continues to act in redemptive missional love towards the lost world. God revealed the true nature of love when Godself became the truth, the life and the way in Jesus Christ. For Bosch ([1991] 2005:390) the missio Dei concept is not 'primarily an activity of the church, but an attribute of God'. God is a missional God and the one that sent the Son to redeem the world. The church has no salvation to offer but through the Father, Son and Holy Spirit. There is no equality between God and creature and yet God gives of Godself, the Son, to raise man for a greater parity. The possibility that humankind can be in a healed relationship with the almighty God could only have been organised and orchestrated by God. This act of God, to restore the relationship between humankind and God, is thereby seen as a movement from God to the world; the church is an active instrument, greatly privileged to participate in God's mission. The church exists because of mission and not vice versa. The church participates in the movement of God's love towards people (Bosch [1991] 2005:390). Flett shows how the Trinity relates to us: the Father as our Creator, the Son as our Redeemer by his blood, and the Holy Spirit as our Sanctifier by living in our hearts (Flett 2010:6). The missional church knows that it is God who is on a mission and that the church joins him in reaching out to the world. It is imperative that the church finds out what God is doing and joins in it (McNeal 2009:23).

\section{Relational Trinitarian ecclesiology}

'God is love' (1 Jn 4:8) and love found a church through mission. Mission belongs to God because the initiation and action come from him. Mission is also what God is in his deepest self: perfect love and affection, creating, healing and redeeming. God gave his Son without holding back and keeps pouring out divine goodness on the world. The Son was the incarnation of mission that conveyed a lifestyle to the disciples and through the disciples to the world. 'The mission began to have a church' (Bevans \& Schroeder 2011:13) and the church is the extension of who God is. If this is not the case, the church fails to express its core being. The proclamation of being founded by God himself then becomes a claim without essence or substance. The church is incarnational and as the body of Christ represents the missio Dei in any community and culture it finds itself in. According to Sweet (2009:27), incarnation is how the church lives: it is a lifestyle. Niemandt (2012:3-4) says that the church does what it is and then organises what it does. The church has to be incarnational instead of attractional, because the presence of God dwells within the church and is physically brought into places and situations where it otherwise is not to be found.

The journey of discovering the community and its relationship in the Trinity as well as the community and relationship of Trinity to creation, sets an example and standard of who and what the church should be. God is love and there is a missional relationship between the Godhead and creation. 'Relationships didn't begin as a human initiative' (Saccone 2009:14), instead, it all started with God and the relationship within the Trinity. God created humans as relational beings because God exists as a relational being. As we are made in the image of God, God's desire for us is to enjoy the kind of community and relationship that 'He experiences within Himself (Father, Son and Spirit)' (Saccone 2009:14).

The essence of being church is the notion of missio Dei: God is missional, the church is missional, and the church has no mission but the "mission of God"' (McKnight 2007:135). The life of Christ brings the revelation of the relationality, community and missionality of the Father, Son and Holy Spirit to us and the church should act accordingly. The 'lifeblood' of the church comes from the being and character of the triune God. If God loves the world, then the church must love the world. If God engages the world in a loving and caring relationship through the Son, then that is the only acceptable way the church should engage the world. 
The missio Dei as the act of God to save the world involves a Triune God with the 'grace of the Lord Jesus Christ, and the love of God, and the fellowship of the Holy Spirit' (2 Cor 13:14) in its fullness. Koinonia with the Father through Christ, made possible by the Holy Spirit, makes the church a relation-based community. The church is a community of family members who are all free and equal. There is no hierarchy, for it has been replaced by a covenant. In Christ no one has a higher or lower position; in his church, no one is above the other, and every one is a witness, bringing to the community what they received from the Holy Spirit.

\section{The Trinity and relational leadership}

The argument presented in this article is that the mission of the church is far more about God and who God is than about the church and what the church does. The church is life in the Trinity, and the organisation and understanding of leadership in the church must therefore reflect this life in the Trinity. The observation made in a study document of the Reformed Ecumenical Council (REC) confirms the importance of looking at the Godhead for the template of leadership, saying that ' $[L]$ eadership is missionally directed and grounded in the Missio Trinitatis' (REC 2005a:28).

The Father sent his Son because of his loving relationship with the world. Tennent says that the "Trinity is the seminal relationship that lies behind all human relationships' (Tennent 2010:loc 769). Being our Father, God is with us, beside us, in us, connected to us, and related to us. This fundamental relationship that comes from the Father is the inspiration of the church which reaches out to the world. 'God so loved the world' is followed by the missional act of giving, caring, touching and saving.

\section{Incarnation of a relational God}

The same focus on relationality can be seen in a consideration of the incarnation - it is relevant to leadership and church organisation, because it is much more than a story of how God became man. Jesus entered the history of the earth to become part of the culture of people and entered into their 'shared consciousness', 'shared traditions', 'mental processes and patterns of relationships' to take part in human life and become the archetypal missionary (Tennent 2010:1oc $697-701,818)$. He came to reveal a relational Father, the One who so loved the world that he gave his Son. This gift was a relational gift (Sweet 2009:119) and through him there can be a restored relationship with the Father.

In following Jesus, the church 'imitates' the incarnation of Jesus, and thus the church can say 'Thy will be done' and 'Jesus is the Way, the Truth and the Life'. This is not only a proposition, but a relational and missional lifestyle with Jesus' elevated relationship with the Father as a paradigm of the church's relationship with the Trinity (Sweet 2009:19). This assertion comes from Jesus' claim to be in a unique relationship to his Father which God confirmed through the resurrection (Grenz 2000:260-262). Jesus then asks his followers to follow in his likeness. The church engages in Kingdom acts through relationships, such as reconciliation, healing, caring and ministering to the needy, and in doing so participates in God's redemption and restoration. Through the Holy Spirit the church helps others to also experience wholeness and restoration. A church that is patterned in the image and likeness of God functions in a confused world to bring reconciliation and healing (Bergquist \& Karr 2010:64).

To empower the church to live a God-incarnated life, the Holy Spirit was sent to comfort, teach, remind and guide the church. The Holy Spirit leads by empowering; when he is seen in the context of a teacher and comforter, it suggests an ongoing relational leadership.

With the church being a relational and missional community, there is no doubt that the leadership must have the same focus. The understanding of missional leadership must thus be rooted in the understanding of the Trinity:

The recent Trinitarian renaissance has wrought several advances and, despite nuances, wide consensus exists that the Trinitarian confession identifies the Christian understanding of God, who has revealed himself as being-in-relation. Apart from revisioning all major doctrines in a Trinitarian way, the trinity is utilised imaginatively to address heuristically fundamental problems, e.g. social and gender relations and religious plurality. (Niemandt 2008:19)

The REC (REC 2005b:28) responded to these challenges with the following description of a Trinitarian orientation of leadership:

- Leadership orientated on God the Father as Creator is ecologically sensitive, non-dichotomous and nonsectarian.

- Leadership grounded in Christ as Messiah means emptying oneself and not shying away from sacrificial service.

- Leadership based on the Spirit is dynamic, charismatic and creative.

- Leadership is missionally directed and grounded in the Missio Trinitatis.

- Leadership is eschatologically motivated by the vision of the Kingdom of God.

Leadership and the associated relations are thus conceived from the Trinity - the relationship between the persons in the Holy Trinity (Gibbs 2005:117). Church life and church leadership must reveal something about the life within the Trinity. As the Triune God exists in relationship, it is impossible to think about church and leadership without thinking about relationships (Niemandt 2008:20). Cole (2005:123-128) describes supportive relationships as part of the DNA of the church. 'If God is defined in relationships, then so is the church' (Taylor 2005:loc 1632).

\section{Relational leadership}

It has been argued that mission is an extension and amplification of God's very being. The journey of discovering community and relationship in the Trinity sets the example 
and standard of who and what the church should be Missional theology builds on the understanding that God is Trinity and missional. In the rest of this article, it will be argued that relational leadership (RL) is an appropriate leadership style for expressing the true nature of church life as life in the Trinity and thus relational.

If leadership is about anything, it is about relationships. In theory and praxis, RL is closely related to servant leadership, but with the focus on relationships rather than serving. RL is being attuned to and involved with the intricate web of interand intrarelationships within an organisation. Relational meaning and identity are created when people live, work and fellowship together. Dyer (2001) describes the importance of the perceptions of people in RL as follows:

Regardless of the rules, structures or roles and irrespective of tasks, strategic plans, political alliances, programs, contracts, lawsuits, etc., relational leadership is about people and their perceptions (which in essence, are their realities) of how they are being treated and valued. (n.p.)

Partnerships, followership, empowerment, teams, networks, and even the future are being examined through this magnifying glass. In Leadership and the New Science (1999), Wheatley argues for a new leadership paradigm - she bases the profile of newer organisations and leadership on a specific cosmology that is an understanding of the structure of the cosmos informed by quantum physics. Her results interface with recent management theory: in a quantum world 'relationship is the key determiner of everything'. Consequently, ' $[L]$ eadership is being examined now for its relational aspects' (Wheatley 1999:11, 13; REC 2005a:45).

RL refers to a model or perspective on leadership that focuses on the idea that effective leadership has to do with the ability of the leader to create positive relationships within an organisation. As this definition indicates, RL has the power to unleash the potential of the individual together with that of the organisation through relationships. The reality of the relational world we live in demands a leadership strengthened with relationships.

RL starts with relational intelligence (RI) and successful leaders create relational health and wellbeing around them because their influence has the best result wherever healthy relationships exist (Saccone 2009:15). RI serves RL and is thus an integral part of the relational nature of the church as imago Trinitatis (Leene 2013:26).

\section{Relational intelligence}

'RI is the ability to learn, understand, and comprehend knowledge as it relates to interpersonal dynamics' (Saccone 2009:20). Saccone sees this definition as the foundational framework for learning more and developing a person's relational capacity to apply RI to leadership. Awareness of RI should be deliberately encouraged, stimulated and strengthened to develop into a quality that is invaluable to any individual or organisation for being equal to the challenge at hand.
In the past, position and status gave a person authority and credibility. Today they are built on relationship and trust (McNeal 2009:146; Saccone 2009:10). Relationally intelligent leaders move away from a positional mindset to a mindset of relational authority. If such leaders wish to expand their influence, they must make sure that a good foundation of RI is laid. It is highly possible that there is a direct connection between the success of a missional community and the RI of its leadership. Poor relational skills can increase the possibility of conflict, whilst a higher level of RI will help eliminate ongoing conflict. Addington (2012) points out that because of poor RI, individuals communicate what they 'think' others want to hear, to gain acceptance. The problem is that it leaves relationships even more clouded. The capacity for RI can be the cause of a leader's failures or successes.

Pursuing RI is a process of discovery that requires attention, focus and intentionality if leaders desire to grow in it. To improve in this arena, leaders must develop the ability to recognise new dimensions of interpersonal dynamics and become smarter in their responses and applications of RI. By cultivating RI, they can enhance their ability to affect the people around them more positively. The more relationally intelligent people become, the more they will demonstrate increased love, respect, and trust in every relationship, which will inevitably elevate their influence. It does not take a relational genius to become more relationally intelligent (Saccone 2009:51). It does not take a specific personality type or temperament or having certain life experiences, background or history to be able to improve on RI. It takes anybody who is willing to step up to the challenge of embodying this 'new way of being smart'.

\section{The relational leader}

The church does what it is and then organises what it does. This is especially the case when the focus is on leadership, as leadership reveals something of the relational life of the church. It has been argued that the most appropriate form or style of leadership is that of the relational leader - a person who is doing all he or she can to be as competent in relationships and RI as possible. Leadership is not only about the leader. Leadership also includes those who are led and choose or agree to follow the leader (Sweet 2004:169). Without followers there can be no leader. Moreover, a leader that puts his or her personal agenda before that of the followers and organisation is a liability (Maxwell 1995:loc 3459).

The relational leader will grow in RI through centring his or her leadership style on relationships. 'Great leaders are followed because people respect and trust them, not because they have position power' (Blanchard \& Barret 2011:171).

RL should develop and expand the missional understanding of a more biblically based model of leadership and thus assist the church to focus and change to the missional character of God.

RL poses a great challenge to everybody. Kouzes and Posner (2003:loc 278-300, 2007:28-37) researched the characteristics 
and attitudes people want from a good leader. According to them, it is all about the credibility of the leader (Kouzes \& Posner 2003:loc 3074-3076). Credible leaders are normally hopeful and optimistic. They inspire with positive images and actions. They are supportive and enable others to excel. It is possible to develop a RL theory, taking all these findings into consideration and against the background of life in the Trinity.

\section{Relational leadership theory Leadership is a function}

The old functional leadership model had a functional focus without regard to the emotional or personal dimension of the leader; people were seen as tools and interchangeable subjects. In this paradigm the organisation worked with a set of behaviours to help the group perform the task and reach the set goals. This old model placed the emphasis on 'how' the organisation is being led rather than 'who' has been assigned a leadership role. This culture caused the leader to relate to followers in the same manner:

Such impersonal leadership increasingly fails today. Resonant leaders shatter the old leadership mould that was cast in the image of the captains of industry, those old-fashioned leadfrom-the-top figures of authority who led largely by virtue of the power of their position. Increasingly, the best of the breed lead not by virtue of power alone, but by excelling in the art of relationship, the singular expertise that the changing business climate renders indispensable. Leadership excellence is being redefined in interpersonal terms as companies strip out layers of managers, as corporations merge across national boundaries, and as customers and suppliers redefine the web of connection. (Goleman 2002:247-248)

Sweet (2004:34, 2012a:34, 2012b:63) says that 'leadership is at best a function'. The body metaphor of Romans 12 presents the best example of 'body parts' fulfilling a function and even a leadership role when needed. Prophesying, serving, encouraging and leading are all leadership functions. Notable is the relational attributes that exist within the functioning body, namely generosity, diligence, mercy, cheerfulness, love, goodness, devotion and honour. No part of the body may assume a different function or control. There may be support and assistance where necessary but each body part fulfils its calling. Leadership is a function wherever and whenever it is needed. The richness of this metaphor is revealed when it is considered against the backdrop of the arguments made for the importance of RL and RI as expressions of the church's life in the Trinity. Different parts of the body are gifted with specific missions by the Trinity, to participate in the mission of God. Leadership is thus imbedded in the imago Trinitatis. The metaphor of one body and mutual interdependence and self-sacrifice illustrates the interrelationality of the church as an image of the Triune God.

\section{Leadership is contextual}

Friedman's flat world (Friedman 2007) and the fast changing environment in which leaders face, are creating a specific and unique context for leadership. Not only who you are, but also when and where you are matter in leadership. Leadership has a postcode - it must be contextually relevant and appropriate. Within this contextual framework, leaders need to develop an awareness and ability to adapt to the context. This poses the challenge of contextual intelligence: 'Contextual intelligence is an underappreciated but all-encompassing differentiator between success and failure' (Sweet 2010:49). Any individual who was successful in one setting would not naturally be successful in a new setting. The ability to succeed in multiple contexts is based on what is called adaptive capacity - the ability to change one's style and approach to fit the culture, context, or condition of the new challenge. 'Success in the twenty-first century will require leaders to pay attention to the evolving context' (Mayo 2007).

Leadership is a place and a time. God's help and guidance is contextual. Each situation is enveloped by place, time and circumstances. This affects the way Christianity is being presented and how the church involves itself with the population and the environment. It is important that a living God, who exists in an innovative relationship with his creation, should show the way. Leaders must, through discernment and the empowerment of the Holy Spirit, be able to adapt and decide how to take part in God's missional praxis.

\section{Leadership is shared interdependency}

Leadership is shared interdependently in a body. With God as the head, the body works together, serving and protecting. The body metaphor of Romans 12 has already been used to illustrate the interrelatedness of members of the Christian community and represents the best example of 'body parts' fulfilling a function and even a leadership role when needed. Stark (2005:loc 1234) calls it an unfolding leadership, that unfolds within an organically functioning body. Any part of the body can take on a leadership role depending on the need of the body, but 'no leadership function is designed to function alone' (Hirsch \& Catchim 2012:loc 2275). Body parts therefore need each other to be a functional part of the body. Hirsch and Catchim (2012:loc 2922) show the levels of leadership in Ephesians 4 as different functions in the body (with the differences amongst them) to make sure the leadership team represents a well-functioning body. Their leadership consists of the apostolic, the prophetic, the evangelical, the pastoral and the teaching teams. These can be seen as some of the functions of leadership in the body (Eph 4:11-13).

Interdependence reflects the unity of the body of Christ in the midst of diversity. Different parts of the body are gifted with specific missions by the Trinity, to build up the body as a whole. As the body functions in the way God intends, he uses it to draw people of varied circumstances to the good news of Jesus Christ. In interdependent living, the members learn to appreciate the uniqueness that the other is bringing to the relationship. 


\section{Leadership is a relationship}

Leadership has always been about relationships, from a cold, mostly one-sided relationship where followers were only a means to an end, to a warm, interpersonal relationship of caring and cooperation towards a common goal. Whatever the state of the situation, it is a given that there is always some kind of relationship or connection between leaders and followers. However, in a postmodern and pluralistic world, the nature of that relationship has changed. Sound leadership is not only about developing a vision and then casting it to others, but instead, helping and empowering others to find their own vision and releasing it (Cole 2010:86). Relationships encourage and foster collaboration by being interested in another person's joys and pain, treating people with dignity and respect. Saccone (2009:76) is sure that if leaders take the time to get to know what is most sacred about people, they will also be invited to have the most sacred kind of influence in people's lives.

Leadership is a relationship (Kouzes \& Posner 2007:23, 24). It is a relationship between partners and fellow workers. It is the quality of these relationships that matters when there is a common goal or calling to answer to, and a community of people finding themselves engaged in getting extraordinary and astonishing things done. 'A relationship characterised by mutual respect and confidence will overcome the greatest adversities and leave a legacy of significance' (Kouzes \& Posner 2007:24). Considering the theological significance of life in the Trinity and the description of the church as imitating the Trinity, and recognising the link between imago Trinitatis and the church, it is clear that this affects the understanding and nature of leadership in the church:

Through our connection with Christ we have the responsibility and privilege of reflecting the nature of the Triune God. And as a result of this relationship the Holy Spirit is now transforming the members of the church into the image of God in Christ. (Leene 2013:231)

\section{Leadership is balance}

The relational leader can never lose sight of the vision and purpose of the mission, and although the leader must do everything to keep relationships intact, the mission cannot be compromised. Christ, who can be seen as the perfect relational leader, never let go of his Father's will even when one of his disciples tried to interfere with his mission. He was not unsettled or redirected by Peter's vigorous rebuke described in Matthew 16:21-23.

Business leaders who acknowledge the importance of relational development in the corporate world also realise that relationships cannot compromise any company's mission or its results. Blanchard (2010:278) suggests that leaders value both results and relationships and see both as critical for long-term survival. Although for some corporate leaders it is all about results, Blanchard points out that without the commitment of its followers, getting good results is almost impossible: 'The way to maximise your results as a leader is to have high expectations for both results and relationships' (Blanchard 2010:279). If leaders can create a motivating environment for their people, profits and financial strength are the applause they get for a job well done, says Blanchard. 'You see, success is both results and relationships' (Blanchard 2010:279). Good leaders know where they are going and are able to persuade others to follow (Maxwell 1995:loc 2500).

There might be a fine line between being committed or overcommitted to relationship. Over-commitment to saving a relationship can ruin the mission; likewise, a leader who cannot say 'no' cannot be a leader (Saccone \& Saccone 2012:loc 978-981). The art of leadership is all about the art of finding a balance between the relational and the visional.

\section{Organisational chart of a relational leadership style}

It is possible to illustrate RL theory using the wellknown metaphor of organisational charts. The dominant organisational metaphor might still be the hierarchy and is organised by rank and authority where people are referred to as superiors or bosses and subordinates. When considering the word 'subordinate', it immediately suggests a person under the authority or control of another within an organisation. It also means that such a person is treated or regarded as of lesser importance than someone else, derivatively given the idea of being inferior to another.

The 'top-down' hierarchical structure can be illustrated by using an organisational chart (Figure 1).

This superior cum inferior culture with its pyramidal chain of command structure became unacceptable in a postmodern society and has always been unacceptable in God's church. The position of the leader in an organisation need not be high up on a hierarchical organisational chart so he or she can be followed. With leadership as a function and the leader being a person with solid characteristics and relational skills, people will follow willingly. Maxwell's (2005:7) statement may seem direct and harsh, but it is true: 'Leadership is a choice you make and not a place you sit.'

Emerging leadership styles like servant, organic and RL styles are becoming more and more acceptable and take a definite stand against the older, traditionally top-down structures (Avery 2004:27; Cole 2009:loc 1020).

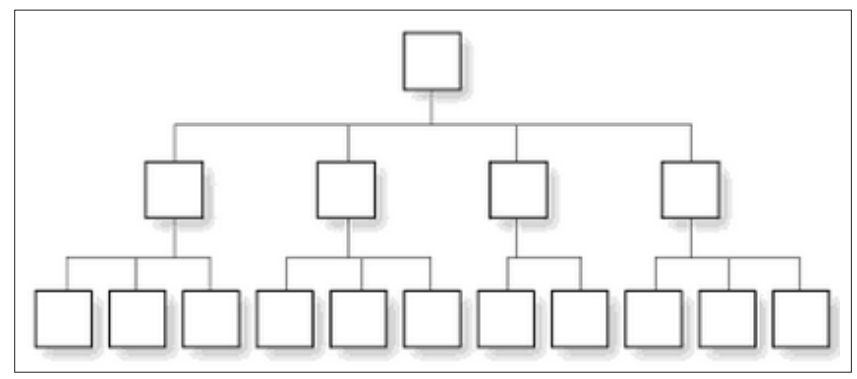

FIGURE 1: The Top-down hierarchical structure. 
Cole (2009:88) proposes a flat structure that shows equality amongst partners. However, it does not suggest any relationship (Figure 2).

The relational organisational structure is a web of connections (Figure 3). Within this structure there is no supreme governing body or person.

The structure shows leaders in primary and secondary leadership relations, with no hierarchy at all. Several leaders in different ministries meet regularly in an informal manner and although there is accountability to each other, everyone in the relationship takes full responsibility for his or her own ministry. Every leadership function, for example the organising of larger or smaller fellowships and the ministry during such occasions, mentoring businessmen, or coaching young emerging leaders with developing RI, operates independently but in a relationship and accountability within the relationship circle (Breedt 2009:66). It is called the relationship, consensus, consent and accountability (RCCA) model and the informal rule is that even if consensus cannot always be reached, support and consent is given because it is a relationship built on trust.

\section{Uniting relational leadership and the missional church}

One of Jesus' clearest statements can be found in Matthew 20, where he spoke about basic leadership contrasts - the difference between leadership that reflects God's Kingdom and leadership that works against that which he came to demonstrate (Stark 2005:loc 64):

Jesus called them together and said, 'You know that the rulers of the Gentiles lord it over them, and their high officials exercise authority over them. Not so with you. Instead, whoever wants to become great amongst you must be your servant, and whoever wants to be first must be your slave just as the Son of Man did not come to be served, but to serve, and to give his life as a ransom for many'. (Mt 20:25-28)

This is exactly the approach of reciprocal service that serves relationality (Leene 2013:273).

\section{Eldership as relational leadership}

Peters' advice to the church is totally in line with Jesus' explanation of the character, qualities and workings of the Holy Spirit as described by John. The Holy Spirit is the great $\pi \alpha \rho \alpha ́ \kappa \lambda \eta \tau$ [paraclete], the Helper, Counsellor, Encourager, Mediator and Assistant (Jn 14:16, 26; 15:26; 16:7; 1 Jn 2:1) (Swanson 2001). This is how the elders must function with the help and guidance of the Holy Spirit (1 Pt 5:1-5).

It is clear that Peter does not consider himself of higher authority or position than the other elders of the church. He sees himself as one of the leaders of the church

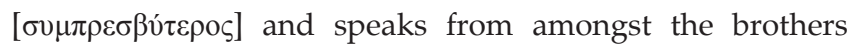
and not from above. His approach to the issue of eldership emerges when he recommends that they do not lord over those entrusted to them. They are not to rule, overpower or

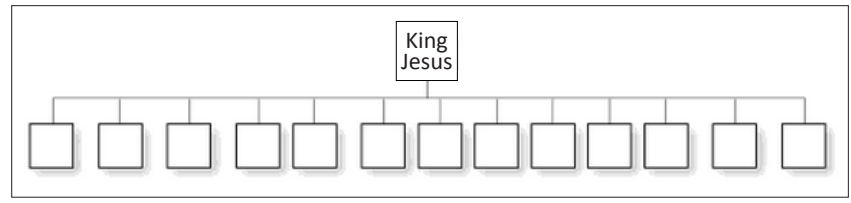

FIGURE 2: The flat structure.

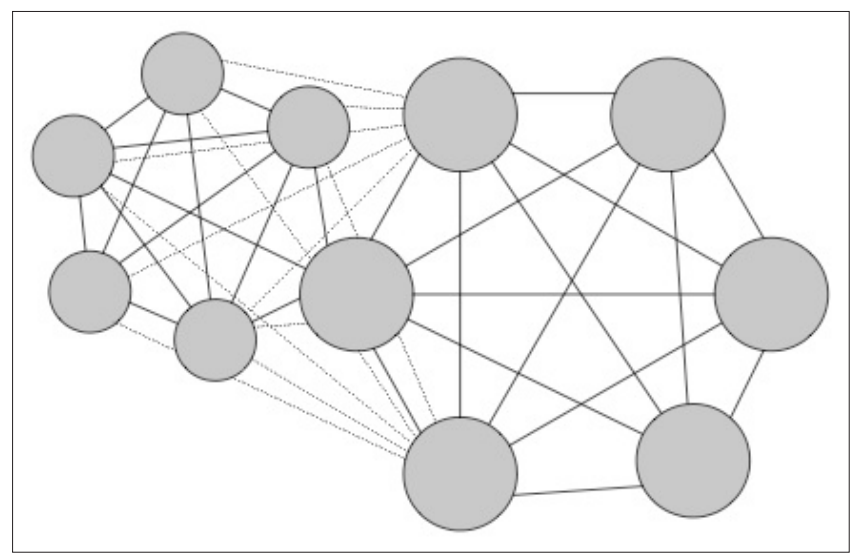

FIGURE 3: Relational structure.

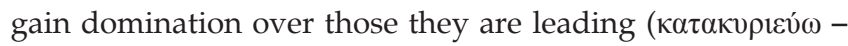
Swanson 2001), but to lead by going before them by example. The example is one of servant leadership and mutual submission.

Overseer as used in Acts 20, 1 Timothy 3 and Titus 1 does not suggest that one person looks down on another. Episkopos

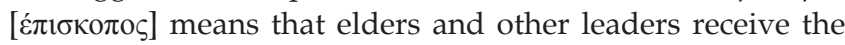
calling to keep watch or look out for those serving God with them. In his word studies from the New Testament, Wuest

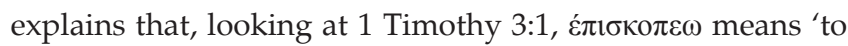
look over, to oversee, to superintend, to exercise oversight or care over' (Wuest 1997). Kittel (1964:608) notes that غ́лíбколо is used with the understanding of the 'onlooker' as 'watcher', 'protector' and 'patron'. Cole (2009) summarises eldership as follows:

Yes, there are apostles, prophets, evangelists, shepherds, and teachers in the New Testament, and these people should be amongst the churches as well. But this does not mean we must assume a top-down structure. Overseer does not mean the person is over the others looking down; it means he is amongst the others looking over (1 Tim. 3:1-7; Titus 1:7-9). Leaders are to 'keep watch [looking out] over your souls' (Heb. 13:17). (p. 90)

Eldership is a leadership that leads and serves with the gifts of the Spirit (1 Corinthians 12) by living the fruit of the Spirit as the example from within the church. The fruit of the Spirit, comprising of love, joy, peace, forbearance, kindness, goodness, faithfulness, gentleness and self-control, is a life 'by the Spirit' and is in totality a relational package (Gl 5:22). In terms of the importance of RL, the emphasis is on the relationship the elders must have with the members both groups are in Christ and their relationship is redeemed through the work of Christ. The structure of Trinitarian relations is not characterised by a pyramidal dominance of one or a hierarchical bipolarity between one and many, but rather by a polycentric and balanced reciprocity by many (Leene 2013:277). 


\section{Relational leadership as missional leadership}

The church needs an appropriate missional understanding of leadership to organise and transform itself into missional life. Relational consciousness is the power behind successful missionality and moves the church 'beyond the "task" of evangelism' (Sweet 2009:112). When we examine the leadership styles that will improve missionality, such as situational, servant, shared and organic leadership, relationship is the core component of all these leadership styles. Missiology can be seen as an act of God to bring the church into relationship with him and into community with one another so that he can reveal his love to the world. In the church's relationship with the Trinity, God continually transforms and renews their relational worlds towards their capacity to internalise his love so that his church can externalise it to others (Saccone 2009:19). Thinking about church structure in a consistently Trinitarian way means seeing not only the clerical roles but also the entire local church itself - and all leadership - in terms of the Trinity.

Sweet $(2009: 111,112)$ notes that in his final words Jesus did not start the Great Commission with 'go' but by saying and thus confirming that 'All authority in heaven and on earth has been given to $\mathrm{Me}^{\prime}$ ( $\mathrm{Mt}$ 28:19). With authority as a relational word, it states Christ's heaven and earth's relationship and connections, and only this makes the Great Commission plausible. The church's commission and missionality is not a project or even a response to a command, it is an ongoing relationship with Christ: 'as you are going with me, hearing me, being me, following me, draw others into our relationship' (Sweet 2009:112).

\section{Conclusion}

There is an urgent and unceasing peremptory demand made on the ability of leaders in the familiar church today to rethink the role of their leadership. The demands of the current era have to be accommodated in the church and the assistance of the Holy Spirit is indispensable.

Relationships are not something the church does. Relationships are what faith is (Sweet 2009:27) because we serve a missional, relational and incarnational God. 'God cannot be God in propositions. God can only be God in relationships' (Sweet 2009:120).

If God is the perfect example of relationship, his church can only exist in relationships, church leadership and eldership can only function in relationships and missionality can only be successful in relationships.

\section{Acknowledgements Competing interests}

The authors declare that they have no financial or personal relationship(s) that may have inappropriately influenced them in writing this article.

\section{Authors' contributions}

C.J.P.N. (University of Pretoria) was the project supervisor, made conceptual contributions and contributed to the research. J.J.B. (University of Pretoria) made conceptual contributions and completed most of the design and research.

\section{References}

Addington, T.J., 2012, Relational intelligence: Leading from the sandbox, viewed 28 August 2012, from http://leadingfromthesandbox.blogspot .com/2012/04/ relational-intelligence.html

Avery, G.C., 2004, Understanding leadership, Sage Publications, London.

Balia, D. \& Kim, K. (eds.), 2010, Witnessing to Christ today, Regnum Edinburgh 2010 Series, vol II, Regnum Books International, Oxford.

Barna, G., 2005, Revolution, Tyndale, Caroll Stream. PMCid:PMC1182201

Bergquist, L. \& Karr, A., 2010, Church turned inside out: A guide for designers, refiners and re-aligners, Jossey-Bass, San Francisco.

Bevans, B. \& Schroeder, R.P., 2011, Prophetic dialogue: Reflections on Christian mission today, Orbis, New York.

Blanchard, K. \& Barret, C., 2011, Lead with LUV: A different way to create real success, Polvera Publishing, Upper Saddle River.

Bosch, D.J., [1991] 2005, Transforming mission: Paradigm shifts in theology of mission, Orbis, New York.

Breedt, J.J., 2009, 'Kerk 24/7 -'n Gevallestudie van'n ontluikende geloofsgemeenskap in George', MTh thesis, Stellenbosch University, Stellenbosch.

Cole, N., 2005, Organic church: Growing faith where life happens, Jossey-Bass, San Francisco.

Cole, N., 2009, Organic leadership: Leading naturally right where you are, Baker Books, Grand Rapids.

Cole, N., 2010, Church 3.0.: Upgrades for the future church, Jossey-Bass, San Francisco.

Dyer, K.M., 2001, Relational Leadership, AASA Center for Creative Leadership [online], Greensboro, viewed 14 August 2012, from http://www.aasa.org/ SchoolAdministratorArticle.aspx?id=10672\&terms=relational+leadership

Flett, J.G., 2010, The Witness of God: The Trinity, Missio Dei, Karl Barth and the nature of Christian community, Eerdmans, Grand Rapids. (Kindle edition). PMCid:PMC2887857

Friedman, T.L., 2007, The World is Flat, Picador, New York.

Gibbs, E. \& Coffey, I., 2006, ChurchNext, InterVarsity Press, Leicester, England.

Gibbs, E., 2005, Leadership Next, Downers Grove, InterVarsity Press, Illinois.

Goleman, D., 2002, with Boyatzis, R. \& McKee, A., Primal leadership: Realizing the power of emotional intelligence, Harvard Business School Press, Boston.

Grenz, S.J., 2000, Theology for the community of God, Eerdmans, Grand Rapids, Michigan. (Kindle edition).

Grenz, S.J., 2004, Rediscovering the Triune God: The Trinity in contemporary theology, Fortress Press, Minneapolis. (Kindle edition).

Hirsch, A. \& Catchim, T., 2012, The permanent revolution: Apostolic imagination and practice for the 21st century church, Jossey-Bass, San Francisco.

Kittel, G. (ed.), 1964, Theological dictionary of the New Testament, Eerdmans, Grand Rapids.

Kouzes, J.M. \& Posner, B.Z., 2003, Credibility: How leaders can gain it and lose it, why people demand it, Jossey-Bass, San Francisco.

Kouzes, J.M. \& Posner, B.Z., 2007, The Leadership challenge, 4th edn, Jossey-Bass, San Francisco.

Leene, A.M.J., 2013, Triniteit, antropologie en ecclesiologie: Een kritisch onderzoek naar implicaties van de godsleer voor de positie van mannen en vrouwen in de kerk, DTh thesis, Stellenbosch University, viewed 18 June 2013 from, http://hdl. handle.net/10019.1/80176

Limb, P., 2008, Nelson Mandela - A biography, Greenwood Press, Connecticut, London. (Kindle edition).

Mandela, N., 2011, Greatest quotes, Greatest Quotes for Kindle, South Africa. (Kindle edition).

Maxwell, J.C., 1995, Developing the leader within you \& developing the leaders around you, Injoy, Georgia. (Kindle edition).

Maxwell, J.C., 2005, The $360^{\circ}$ leader: Developing your influence from anywhere in the organization, Thomas Nelson, Nashville, Tennessee.

Mayo, T., 2007, Context-based leadership, Harvard Business Review [online], viewed 01 September 2012, from http://blogs.hbr.org/mayo/2007/07/ contextbased_ leadership_1.html

McKnight, S., 2007, A Community called Atonement, Abington Press, Nashville.

McNeal, R., 2009, Missional Renaissance: Changing the scoreboard for the church, Jossey-Bass, San Francisco.

Moltmann, J., 2010, Sun of Righteousness, Arise!: God's future for humanity and the earth, SCM Press, London. 
Niemandt, C.J.P., 2008, " $n$ Stormkompas in tye van aanpasbare verandering: Kontoere van missionêre leierskap' [online], Verbum et Ecclesia, viewed 01 August 2012, van missionêre leierskap' [online], Verbum et Ecclesia, viewed
from http://www.ve.org.za/index.php/VE/article/view/38/35

Niemandt, C.J.P., 2012, 'Trends in missional ecclesiology', HTS Teologiese Studies/ Theological Studies 68(1), Art. \#1198, 9 pages. http://dx.doi.org/10.4102/hts. v68i1.1198

Reformed Ecumenical Council (REC), 2005a, Minutes of the Reformed Ecumenical Council Session at Utrecht, 12-26 July 2005.

Reformed Ecumenical Council (REC), 2005b, 'Clerical and Lay Leadership', Report to the REC Netherlands Assembly Utrecht, 12-26 July 2005.

Saccone, S., 2009, Relational intelligence: How leaders can expand their influence through a new way of being smart, Jossey-Bass, San Francisco.

Saccone, S. \& Saccone, C., 2012, Protégé: Developing the next generation of church leaders, InterVarsity Press, Illinois.

Stark, D., 2005, Christ-based leadership, Bethany House, Minneapolis, Minnesota. (Kindle edition).

Swanson, J., 2001, Dictionary of Biblical languages with semantic domains, Greek (New Testament), Logos Research Systems, Oak Harbor. (Electronic edition).
Sweet, L., 2004, Summoned to lead, Zondervan, Grand Rapids.

Sweet, L., 2009, So Beautiful: Divine design for life and the church, David C Cook, Colorado Springs. (Kindle edition).

Sweet, L., 2010, Nudge. Awakening each other to the God who's already there, David $C$ Cook, Colorado Springs. (Kindle edition).

Sweet, L., 2012a, I am a follower: The way, truth and life of following Jesus, Thomas Nelson, Nashville, Tennessee.

Sweet, L., 2012b, Viral: How social networking is poised to ignite revival, WaterBrook Press, Colorado Springs.

Taylor, S., 2005, The out of bounds church, Zondervan, Grand Rapids.

Tennent, T.C., 2010, Invitation to world missions: A Trinitarian missiology for the twenty-first century, Kregel, Grand Rapids.

Volf, M. \& Welker, M. (eds.), 2006, God's life in Trinity, Fortress Press, Minneapolis.

Wheatley, M.J., 1999, Leadership and the new science, Berret-Koehler Publishers, San Francisco.

Wuest, K.S., 1997, Wuest's word studies from the Greek New Testament: For the English reader, Eerdmans, Grand Rapids. (Electronic edition by Logos Research Systems). 